\title{
GABINET RYCIN POLSKIEJ AKADEMII UMIEJĘTNOŚCI - KARTA Z DZIEJÓW POLSKIEJ HISTORII SZTUKI
}

Niniejszy szkic poświęcony jest inauguracji działalności Gabinetu Rycin Polskiej Akademii Umiejętności, z racji przypadającej w bieżącym roku osiemdziesiątej rocznicy tego wydarzenia. Nie roszcząc sobie pretensji do stania się kolejnym opracowaniem historii Gabinetu Rycin ${ }^{1}$, pozostaje przede wszystkim konstatacją stanu naszej wiedzy na temat osób zaangażowanych w powstanie Gabinetu, okoliczności ich działań i wreszcie powodów, dla których instytucja ta popadła w zapomnienie. Uwagi te należy traktować jako okolicznościowy przyczynek wobec nie przebadania ogromnej, istniejącej bazy źródłowej. Zapewne z tym samym problemem zetknęło się wielu badaczy czasów najnowszych, podejmujących trud monograficznych opracowań postaci czy instytucji. Niedostatek szczegółowej wiedzy, np. na temat działalności PAU na polu muzealnym, niezwykle utrudnia zestawianie faktów i interpretację wydarzeń ${ }^{2}$.

1 Jakimi są prace: A. Treiderowa, Zbiór graficzny Biblioteki PAN w Krakowie. Zarys dziejów, „Rocznik Biblioteki PAN w Krakowie”, 2, 1956, s. 349-374; K. Grodziska, Gabinet Rycin Polskiej Akademii Umiejętności i Zbiory Graficzne Biblioteki Polskiej Akademii Nauk oraz ich wystawy [w:] Arcydzieła grafiki XV i XVI stulecia ze zbiorów graficznych Biblioteki Polskiej Akademii Nauk w Krakowie, Kraków 1997, s. 9-21; K. Krużel, The Print Collection of the Polish Academy of Sciences, „Print Quarterly”, XI, 1994, 2, s. 158-166; tenże, Gabinet Rycin Polskiej Akademii Umiejętności 1935-1952, „Rocznik Polskiej Akademii Umiejętności” 1998/1999, s. 200-225.

${ }^{2}$ Działalność muzealna PAU uwzględniana w pracach ogólnych: Z. Jabłoński, Działalność biblioteczna, archiwalna i muzealna PAU [w:] Polska Akademia Umiejętności 1872-1952. Nauki humanistyczne i społeczne. Materiały sesji jubileuszowej, Kraków, 3-4 V 1973, red. Jan Hulewicz i in., Wrocław 1974, s. 73-81 (równocześnie zestawienie dające obraz parcelacji zbiorów po zlikwidowaniu PAU); J. Piskurewicz, Prima Inter pares. Polska Akademia Umiejętności w latach II Rzeczypospolitej, Kraków 1998, s. 82-85; 156-163. J. Dybiec, Polska Akademia Umiejętności 1872-1952, Kraków 1993, s. 68-69 (zbiory graficzne wymienione w ramach Biblioteki PAU), 70-75. Jak dotychczas najpełniejszym opracowaniem tego problemu pozostaje: A. Treiderowa, Kolekcja obrazów, rysunków i rzeźb Polskiej Akademii Umiejętności, „Rocznik Biblioteki PAN w Krakowie”, R. 18, 1972, s. 37-91. 
W piątek, 22 czerwca 1935 roku o godzinie 13.00, przy ulicy Straszewskiego 27 w Krakowie, na pierwszym piętrze świeżo wyremontowanego Domu im. Hussarzewskich, nastąpiło otwarcie Gabinetu Rycin ${ }^{3}$. Uroczystość ta uświetniła zwyczajowe Walne Zgromadzenie PAU (fot. 1). Honory gospodarza pełnił prezes Stanisław Wróblewski (1868-1938), który wygłosił zagajenie. Stawili się członkowie władz PAU, z sekretarzem generalnym Stanisławem Kutrzebą (1876-1946) na czele oraz miejscowi i zamiejscowi członkowie Akademii. Wśród gości zaproszonych na otwarcie Gabinetu i posiedzenie PAU byli przedstawiciele władz kościelnych i świeckich, z których część na różne sposoby związana była z nową instytucją bądź zainteresowana sprawami artystycznymi. Ze strony duchownej zjawił się przede wszystkim metropolita krakowski arcybiskup Adam Stefan Sapieha (1867-1951) zaangażowany w sprzedaż PAU kolekcji graficznej Moszyńskich ${ }^{4}$ oraz dziekan kapituły krakowskiej ks. Marceli Ślepicki (1863-1936), wrażliwy na sprawy sztuki fundator ornatu projektu Zofii Stryjeńskiej do katedry krakowskiej ${ }^{5}$. Arystokrację reprezentowali księstwo Andrzejostwo Lubomirscy, co zrozumiałe wobec faktu, iż w r. 1923 księżna Andrzejowa - Eleonora z Hussarzewskich (1866-1940) - ofiarowała PAU kamienicę przy ul. Straszewskiego wyłącznie na cele naukowe Akademii ${ }^{6}$. Z powodu niemożności przybycia Lubomirskiej do Krakowa na wiosnę zmieniono zresztą pierwotny termin otwarcia Gabinetu planowany na 25 marca $^{7}$. Stawili się członkowie Komitetu Gabinetu Rycin oraz członkowie Komisji Historii Sztuki (KHS), podpisani na liście obecności na publicznym posiedzeniu ${ }^{8}$.

Po zagajeniu prezesa PAU, głos zabrał profesor Leon hrabia Piniński (18571938), przewodniczący Komitetu Gabinetu Rycin, który omówił genezę, historię zbiorów oraz ryciny zaprezentowane obecnym. Pomimo tego, że dopiero pół godziny wcześniej Piniński zapoznał się z zakresem wystawy99, to można przypuścić,

${ }^{3}$ K. Grodziska, op. cit., s. 13-14.

${ }^{4}$ P. Biliński, Sprawa zakupu sztychów po Jerzym Moszyńskim przez Polską Akademię Umiejętności, „Biuletyn Biblioteki Jagiellońskiej, 54, 2004, s. 129, 141. W relacjach brak potwierdzenia aktu poświęcenia Gabinetu przez arcybiskupa Sapiehę, co podawał K. Krużel, op. cit., s. 207.

${ }^{5}$ Wawel 1000-2000. Wystawa jubileuszowa, t. 1: Kultura artystyczna dworu królewskiego i katedry. Zamek Królewski na Wawelu, maj-lipiec 2000; Katedra krakowska - biskupia, królewska, narodowa, Muzeum Katedralne na Wawelu, maj-wrzesień 2000, red. M. Piwocka, D. Nowacki; t. 3: Ilustracje, Kraków 2000, s. 267, kat. I/261 (oprac. K. J. Czyżewski); t. 3, il. 333.

${ }^{6}$ „Rocznik Polskiej Akademii Umiejętności. Rok 1933/1934”, 1935, s. 112.

${ }^{7}$ Archiwum Nauki PAN i PAU w Krakowie, Polska Akademia Umiejętności, Korespondencja Sekretarza Generalnego (dalej jako: AN PAN i PAU Kr, PAU, KSG), sygn. 411/1935 - Zaproszenie dla Eleonory Lubomirskiej, 16 III; jej odpowiedź z 19 III ze stanowczą prośbą o zmianę terminu, gdyż w okresie wiosennym ze względu na stan zdrowia nie może podróżować; zgoda sekretarza generalnego z dn. 21 III; druki z datą 23 III informujące o zmianie terminu uroczystego otwarcia wystawy Gabinetu Rycin na prośbę księżnej Lubomirskiej. Członkowie PAU, którzy zjawili się na posiedzeniu, mieli jednak okazję, aby zwiedzić wystawę i Dom Hussarzewskich.

${ }^{8}$ Lista osób obecnych na otwarciu oraz publicznym posiedzeniu - AN PAN i PAU KR, PAU, KSG, sygn. 770/1935 (Walne Zgromadzenie PAU 21. i 22. czerwca). Tutaj także szereg pism z uprzejmym podziękowaniem za zaproszenie i usprawiedliwieniem nieobecności.

9 AN PAN i PAU Kr, PAU, KSG, sygn. 421/1935 - list Pinińskiego do Kutrzeby z 14 IV. 
że wypowiedział się o niej entuzjastycznie jako kolekcjoner i znawca malarstwa angielskiego, którego kolekcję kilka lat wcześniej ofiarował Państwowym Zbiorom Sztuki na Wawelu ${ }^{10}$. Następnie goście udali się do sal wystawowych - czterech pokoi położonych od strony Plant - gdzie wyjaśnieniami służyli kustosz (Adam Bochnak, 1899-1974) i jego pomocnik (Karol Estreicher mł., 1906-1984). Ponad sto rycin angielskich z lat 1750-1825, najpewniej w większości luźnych plansz, powieszono na ścianach w specjalnie zaprojektowanych gablotach. Były to lekko nachylone kasety z przeszkleniem, o konstrukcji umożliwiającej ekspozycję i niwelującej efekt odbijania się okien. Aranżacja ta - widoczna na archiwalnej fotografii, na której Karol Estreicher mł. oprowadza zwiedzających (fot. 2) ${ }^{11}$ - pozostaje w zgodzie z uwagą reportera w krakowskim „Czasie”: „Na zakończenie podnieść należy skromne, ale wytworne urządzenie wystawy" ${ }^{12}$. Uroczystości otwarcia przebiegły zgodnie z planami sekretarza generalnego, który już w marcu pisał:

[...] Proszę więc, by Panowie przygotowali się do oprowadzania gości i pokazywania im sztychów tak, by mogli się od razu rozrzucić po kilku salach, bo inaczej będzie bardzo ciasno. Proszę też o przygotowanie odpowiednich komunikatów do gazet po otwarciu, trzeba będzie bowiem udostępnić muzeum publiczności zwiedzającej [...] oznaczyć godziny zwiedzania, zarządzić odpowiednie dyżury, ustanowić wstępy i ich pobór $[\ldots]^{13}$.

Krótką informację o uroczystości i godzinach otwarcia zamieszczono w „Czasie” ${ }^{14}$, wykorzystując materiały przygotowane przez nieokreślonego przedstawiciela Komitetu Gabinetu Rycin ${ }^{15}$. Wystawa została nadto, obszernie i żywo opisana w „Czasie" ${ }^{16}$. Ks. Tadeusz Kruszyński (1884-1959) zamieścił informację o tym wydarzeniu w tygodniku „Światowid”, a jego artykuł zilustrowano sześcioma fotografiami (fot. 3-8) ${ }^{17}$. Krótką notatkę o otwarciu „nowej placówki artystycznej i naukowej” opublikowano w „Plastyce” ${ }^{18}$, organie bloku zawodowych artystów plastyków.

$\mathrm{Na}$ wybór tematu pierwszej ekspozycji, który tak doskonale współgrał z zainteresowaniami artystycznymi Leona Pinińskiego, wpłynęła najpewniej ówczesna

${ }^{10}$ J. Winiewicz-Wolska, O. Mikołajski, Malarstwo angielskie w zbiorach Zamku Królewskiego na Wawelu, Kraków 2008, s. 7.

${ }^{11}$ Opublikowana w: „Światowid”, 1935, nr 27 (6 VII), s. 18. Klisza: Narodowe Archiwum Cyfrowe, Archiwum IKC, sygn. 1-N-768.

12 (sp.), Gabinet Rycin, „Czas”, 1935, nr 172 (25 VI), s. 6.

13 AN PAN i PAU Kr, PAU, KSG, sygn. 422/1935 - pismo z 18 III skierowane do Pagaczewskiego, przesłane do przewodniczących Komisji mających siedzibę w Domu im. Hussarzewskich.

14 Otwarcie Gabinetu Rycin Polskiej Akademii Umiejętności, „Czas” 1935, nr 169 (22 VI), s. 11.

15 Świadczy o tym daleko idąca zbieżność enuncjacji prasowej z notatką pt. Otwarcie Gabinetu Rycin Polskiej Akademii Umiejętności - AN PAN i PAU Kr, PAU, KSG, sygn. 770/1935 (Walne Zgromadzenie PAU 21. i 22. czerwca).

16 (sp.), Gabinet Rycin, „Czas”, 1935, nr 172 (25 VI), s. 6. Adamowi Bochnakowi przypisano tu kilka nieprawdziwych stwierdzeń dotyczących kolekcji Moszyńskiego.

17 T. Kruszyński, Cuda angielskiej grafiki. Wystawa rycin w Polskiej Akademii Umiejętności, „Światowid”, 1935, nr 27 (6 VII), s. 18-19. Fotografia ryciny Johna Deana wg G. Morlanda, Wdowa (inw. 25 080) na tylnej okładce „Na Szerokim Świecie”, 8, 1935, nr 28 (14 VII) - pt. Smutna wiadomość.

${ }^{18}$ Anonimowa notatka bez tytułu, „Plastyka”, 1935, nr 2, s. 40-41. 
moda na angielszczyznę. Wybór ten był zapewne pochodną obszernego i różnorodnego zasobu rycin angielskich reprezentowanych w obu kolekcjach tworzących wtedy Gabinet Rycin. Pokaz był niewątpliwie efektowny; wystawa dostępna dwa razy w tygodniu od 23 czerwca 1935 do 16 lutego 1936, otwarta w sumie przez 59 dni, ściągnęła 282 zwiedzających ${ }^{19}$. Należy przypuścić, że większość plansz do prezentacji wytypowano z wcześniejszej wystawy zbiorów graficznych PAU, która miała miejsce w r. 1931 w krakowskim Pałacu Sztuki. Za tą tezą przemawiałaby ilość zaprezentowanych rycin oraz nazwiska przytoczone w relacjach prasowych, których gros widnieje w katalogu opublikowanym w r. $1931^{20}$. Dodatkowo pokazano ilustracje do sztuk Szekspira, ryciny Williama Woolleta oraz portrety słynnych osób. Obecność tego ostatniego działu zdradza ikonograficzne, a więc dość zachowawcze podejście do grafiki.

Okoliczności powołania do życia nowej instytucji były przedmiotem wielu opracowań, począwszy od inicjującego temat artykułu Treiderowej, przez poświęcone kolejnym wystawom studium Grodziskiej, aż po faktograficzną pracę Krużla ${ }^{21}$. Pomimo wspomnianych prac, odczuwamy brak kompleksowego, a nie tylko faktograficznego, omówienia. Na tym etapie badań najwłaściwszym byłoby stwierdzenie, że dość dobrze znamy przebieg uroczystości otwarcia: organizatora, miejsce, czas, nazwiska zaproszonych gości, program, a pobieżnie - nawet zaprezentowane przy tej okazji ryciny. Niestety, Gabinet Rycin nie może poszczycić się tak dokładnie rozpoznanymi początkami swej działalności. We wspomnianych pracach cytowane są podstawowe fakty. Zmarginalizowanie okoliczności wydarzeń spowodowało generalne i jednoznaczne połączenie idei powołania własnego Gabinetu Rycin przez PAU z odkryciem tek graficznych podczas reorganizacji Biblioteki Polskiej w Paryżu (1926), skutkującego również zakupem zbioru Moszyńskich (1929) ${ }^{22}$.

Tymczasem wydarzenie to niekoniecznie bezpośrednio wpłynęło na działanie Akademii. Po pierwsze, decyzję podjęto w łonie instytucji, która zmagała się wciąż z prowadzeniem i finansowaniem podległych sobie muzeów: Archeologicznego i Przyrodniczego, a zbiory sztuki - poza przedmiotami „ornamentacyjnymi” - już pod koniec w. XIX przekazała w depozyt ${ }^{23}$. Zaś z drugiej strony - w pierwotnym planie reorganizacji Biblioteki Polskiej, sporządzonym za czasów sekretarzowania

19 K. Grodziska, op. cit., s. 14.

${ }^{20}$ [Z. Ameisenowa], Katalog wystawy dawnych rycin ze zbiorów Polskiej Akademii Umiejętności. Grudzień 1931, Kraków [1931]. Słusznie zauważa K. Grodziska (op. cit., s. 11), że wszystkie prezentacje Gabinetu Rycin opierały się w dużej mierze na pierwszym pokazie zbiorów Biblioteki Polskiej zaprezentowanym w kamienicy Baryczków w Warszawie.

21 Zob. przyp. 1.

22 A. Treiderowa, Zbiór..., s. 356 - spekuluje, że zakup zbioru Moszyńskich podjęto „,wobec spodziewanego przekazania jej [PAU] w bliskiej przyszłości kolekcji graficznej Biblioteki Polskiej w Paryżu”, s. 368 - ,już od r. 1932 przystąpiono w Krakowie do prac przygotowawczych, związanych ze stworzeniem tej nowej, poważnej, krajowej placówki zbiorów graficznych”. Zob. K. Grodziska, op. cit., s. 11; K. Kruże1, op. cit., s. 203.

23 „Rocznik Zarządu Akademii Umiejętności w Krakowie. Rok 1890”, 1891, s. 15; „,Rocznik Akademii Umiejętności. Rok 1891/1892”, 1892, s. 115; A. Treiderowa, Kolekcja..., s. 47-48. 
Stanisława Wróblewskiego, leżało przekazanie rycin „,do jednego ze zbiorów publicznych krajowych (najwłaściwsze byłoby może pomieścić je przy galerii obrazów, np. przy Muzeum Narodowym)" 24 . W kolejnych relacjach z przebiegu prac nadsyłanych w latach 1926-1931 przez Franciszka Pułaskiego (1875-1956), z ramienia PAU zajmującego się restrukturyzacją Biblioteki Polskiej, nawet po odkryciu większej niż zakładano ilości tek graficznych, podtrzymywana jest jedynie decyzja o skatalogowaniu zbioru i jego transporcie do kraju. Również pieczątka, używana w Paryżu do oznaczania zbiorów, wykonana w Berlinie na zmówienie Pułaskiego, określała jedynie właściciela, a nie była deklaracją tworzenia własnej kolekcji ${ }^{25}$.

Często stosowane przez autorów zastępowanie nazwisk korporatywnym ciałem sprawczym (Polską Akademią Umiejętności), niewątpliwie uczytelnia wywód, jednakże pozbawia proces kształtowania się tej idei znamion personalnego wysiłku twórczego. Podległość nowo powstałego Gabinetu Rycin Komisji Historii Sztuki PAU, skłania do postawienia hipotezy, że w gronie jej członków należałoby poszukiwać spiritus movens kreowania nowej placówki - autora pomysłu i konsekwentnego realizatora, niekoniecznie jednej osoby. Ponieważ jak dotąd nie zidentyfikowano takiego promotora ${ }^{26}$, trudno suponować, jakimi motywami się kierowano i jak postrzegano funkcjonowanie i zadania Gabinetu. Rozwikłanie tej kwestii byłoby tym bardziej interesujące, że w relacjach prasowych z r. 1931, omawiających wystawę rycin z Biblioteki Polskiej w Paryżu, rysują się dwie odrębne wizje ,zagospodarowania” zbiorów graficznych PAU. W świetle opinii Stanisławy Sawickiej (1895-1982) ${ }^{27}$, winny być one włączone do już istniejącej kolekcji o charakterze bibliotecznym, gdyż według tej warszawskiej badaczki troska o zbiory muzealne kłóciła się z właściwymi zadaniami Akademii ${ }^{28}$. Podobne stanowisko zajął Franciszek Pułaski. Jego aktywność na polu naukowym i administracyjnym, m.in. praca w Bibliotece Ordynacji Krasińskich (1903-1912) i sekretarzowanie Towarzystwu Naukowemu Warszawskiemu (od 1909), pozwalają sądzić, iż był dobrze

${ }^{24}$ AN PAN i PAU Kr, PAU, sygn. I-126 (Stacja Naukowa w Paryżu) - List sekretarza generalnego, Stanisława Wróblewskiego do Ministerstwa WRiOP zawierający plany reorganizacji Biblioteki, 30 III 1926.

${ }^{25}$ Owalna, brązowa, tuszowa pieczątka, z orłem w koronie pośrodku i z literami P.A.U. - u dołu odbijana na verso plansz zamówienie wspomniane w sprawozdaniu Pułaskiego przesłanym do Krakowa 30 V 1927 (AN PAN i PAU Kr, PAU, sygn. I-127 - Stacja Naukowa w Paryżu). Można zauważyć znaczne podobieństwo znaku do pieczęci ówcześnie używanej w berlińskim Kupferstichkabinett, o tych samych rozmiarach, z orłem pośrodku i literami K.K.K. u dołu - F. Lugt, Les Marques de Collections de Dessin \& d'Estampes, Amsterdam 1921, nr 1634.

${ }^{26}$ Nazwiska tych, których zasługi były największe wymieniają - A. Treiderowa, Zbiór..., s. 368 - Stanisław Tomkowicz oraz Piniński, Pagaczewski, Ameisenowa, Bochnak, Estreicher mł. (autorka nie podaje konkretnych dowodów); K. Krużel, op. cit., s. 203 - Tomkowicz, Lepszy i Piniński (ponieważ Tomkowicz i Lepszy ocenili wartość zbioru Moszyńskich).

27 Por. T. Sulerzyska, Sawicka Stanisława, „Polski Słownik Biograficzny”, 35, 1994, s. 300-302.

${ }^{28}$ S. Sawicka, Zbiór graficzny Biblioteki Polskiej w Paryżu. Na marginesie wystawy sztychów w Kamienicy Baryczków w Warszawie, „Grafika”, 5, 1931, s. 26-37; AN PAN i PAU Kr, sygn. K III-12 (Spuścizna T. Mańkowskiego), nr 347 - list do Mańkowskiego z 9 V 1946. 
zorientowany w problemach kolekcjonerstwa ${ }^{29}$. Pułaski, zapewne około r. 1931, zaproponował utworzenie „Gabinetu Rycin” łączącego zbiory Biblioteki Polskiej w Paryżu oraz dwie kolekcje: króla Stanisława Augusta, rewindykowaną z ZSRR przed r. 1928, i Moszyńskich ${ }^{30}$. Inne stanowisko zajęli anonimowi komentatorzy na łamach „Czasu” i „Sztuk Pięknych”, a także Tadeusz Szydłowski (1883-1942) przemawiający na otwarciu wystawy w Pałacu Sztuki ${ }^{31}$. Postulowali, by zbiory PAU stały się częścią krakowskiego, publicznego zasobu rycin, służącego przede wszystkim udostępnieniu szerokiej publiczności tej kategorii dzieł sztuki. Wszystko wskazuje na to, że zwyciężyła koncepcja potraktowania zbiorów graficznych jako repozytorium dla wystaw czasowych. Z zapisów w sprawozdaniach z działalności Akademii opublikowanych w „Rocznikach PAU”, wynika afirmatywny stosunek władz Akademii do kwestii poszerzania zbiorów o prace współcześnie czynnych artystów-grafików ${ }^{32}$.

Powracając do personaliów i okoliczności powstania idei Gabinetu Rycin, należy rozważyć udział w tym przedsięwzięciu Stanisława Tomkowicza (1850-1933) ${ }^{33}$, $\mathrm{z}$ racji jego zasadniczej roli $\mathrm{w}$ tak skomplikowanych przedsięwzięciach, jakimi były pozyskanie przez PAU ocalałej części zbiorów graficznych Fryderyka Józefa Moszyńskiego (1738-1817) i wkład w inwentaryzację kolekcji Biblioteki Polskiej w Paryżu. Jego pozycja w krakowskim środowisku naukowym, także w ostatnich latach życia, była ugruntowana, o czym świadczy piastowanie funkcji dyrektora Wydziału Historyczno-Filozoficznego PAU (1916-1926) i dyrektora Wydziału Filologicznego (1928-1933). Od r. 1911 aż do śmierci przewodniczył Komisji Historii Sztuki PAU. Doceniano jego działalność konserwatorską oraz w zakresie inwentaryzacji zabytków; zaznajamiano go z najważniejszymi problemami zwrotu polskich dóbr kultury na mocy traktatu ryskiego ${ }^{34}$. Z tej pozycji mógł on dyskutować nad zadaniami Akademii i nadawać jej przedsięwzięciom właściwy kierunek. Partnerem w tej dyskusji był sekretarz generalny, odpowiadający

29 Por. A. Szklarska-Lohmannnowa, Pułaski Franciszek, „Polski Słownik Biograficzny”, t. 29: 1986 , s. 374-380.

${ }^{30}$ F. Pułaski, Biblioteka Polska w Paryżu w latach 1893-1948, Paryż 1948, s. 82.

${ }^{31}$ T. Szydłowski, Wystawa grafiki dawnych wieków w Krakowie ze zbiorów Polskiej Akademii Umiejętności, „Kurier naukowo-literacki”. Dodatek do nru 345 „Ilustrowanego Kuriera Codziennego” z dnia 14 grudnia 1931", nr 50, s. II-IV. O Szydłowskim por. J. Gadomski, Tadeusz Szydłowski [w:] Stulecie Katedry Historii Sztuki Uniwersytetu Jagiellońskiego (1882-1982). Materiały sesji naukowej odbytej $w$ dniu 27 maja 1983, red. L. Kalinowski, s. 61-83.

32 „Rocznik Polskiej Akademii Umiejętności. Rok. 1935/1936”, 1937, s. 22-23 (dar Wandy Komorowskiej); „Rocznik Polskiej Akademii Umiejętności. Rok. 1937/1938”, 1939 (dar Józefa Kluski).

${ }^{33}$ Wzmiankowany przez A. Treiderową, Zbiór..., s. 368; K. Krużel, op. cit., s. 203. Szerzej na temat działalności Stanisława Tomkowicza zob.: T. Łopatkiewicz, Stanistawa Tomkowicza curriculum vitae [w:] Stanisława Tomkowicza Inwentarz zabytków powiatu krośnieńskiego. Z rękopisów autora wydali i własnymi komentarzami opatrzyli Piotr i Tadeusz Łopatkiewiczowie, Kraków 2005, s. 3-5.

${ }^{34}$ Biblioteka Naukowa PAU i PAN, rkps 1988 - Korespondencja S. Tomkowicza, Listy od M. Morelowskiego. 
za sprawy organizacyjne, gospodarcze i finansowe, którym od r. 1926 pozostawał Stanisław Kutrzeba. Było to bez wątpienia silna osobowość, człowiek działający szybko i zdecydowanie, o ile tylko był przekonany co do słuszności swych decyzji ${ }^{35}$.

Włączenie Tomkowicza - posiadającego znaczny dorobek natury inwentaryzatorsko-konserwatorskiej - do komisji powołanej w r. 1926 do oceny wartości kolekcji Moszyńskiego, dokonało się najpewniej za sprawą dyrektora Biblioteki Jagiellońskiej Fryderyka Papée (1856-1940). Niewykluczone, że ważnym powodem była także osobista, bliska znajomość Tomkowicza ze zmarłym testatorem, Jerzym Moszyńskim (1847-1924), a także dobry kontakt z Adamem Stefanem Sapiehą, członkiem kuratorium wyznaczonego przez testatora. Trzyosobową komisję specjalistów zwołano na życzenie Ministerstwa Wyznań Religijnych i Oświecenia Publicznego, które warunkowo zgadzało się rozważyć ewentualność zakupu kolekcji dla Biblioteki Jagiellońskiej. Lustracja ta odbyła się w kamienicy przy ul. Karmelickiej w dniu 29 maja 1926 i potwierdziła wysoką wartość zbiorów. Równocześnie komisja wskazała na skandaliczne warunki przechowywania kolekcji i zaproponowała umieszczenie jej jako depozytu w Bibliotece Jagiellońskiej. Poza Tomkowiczem w skład komisji weszli także Leonard Lepszy (1856-1937) i Tadeusz Szydłowski, również członkowie Komisji Historii Sztuki PAU ${ }^{36}$. Tomkowicz oraz Lepszy podpisali się pod kolejną opinią na ten sam temat, sporządzoną dla Akademii pod koniec r. 1927, przed decyzją o zakupie kolekcji Moszyńskiego. W korespondencji Tomkowicza znaleźć można ślady zainteresowania zbiorem: informacje o przebiegu pertraktacji z Ministerstwem Wyznań Religijnych i Oświecenia Publicznego podjętych jeszcze za życia Moszyńskiego ${ }^{37}$, czy precyzyjne uwagi o sposobie jej skatalogowania ${ }^{38}$. Pióra Tomkowicza jest też pierwsze publikowane omówienie zbioru graficznego Moszyńskich, sygnalizujące jego historię, ale przede wszystkim zawierające rzeczowe i dość szerokie omówienie zasobu pod kątem artystycznym ${ }^{39}$. W końcu - być może - to on zlecił Zofii Ameisenowej (1897-1967), kierującej zbiorami graficznymi Biblioteki Jagiellońskiej, przygotowanie wystawy w r. 1931, prezentującej ryciny z obu zbiorów.

Trzeba skonstatować niemal równoległą aktywność Tomkowicza na polu katalogowania zbioru graficznego Biblioteki Polskiej w Paryżu. Prace rozpoczęła Maria

35 Wielki wkład Kutrzeby w działalność PAU zob. P. Biliński, Stanisław Kutrzeba (1876-1946). Biografia naukowa i polityczna, Kraków 2011, passim. Zdecydowana postawa Kutrzeby ujawnia się zwłaszcza w działaniach, które natrafiły na opór środowiska naukowego, np. w kwestii wycięcia lasów zawojskich w r. 1934 (ibid., s. 121) czy fototeki Lanckorońskich, w której zresztą pewną rolę odegrał Tomkowicz (ibid., s. 135-137).

${ }^{36}$ P. Biliński, Sprawa..., s. 137 (błędnie jako Stanisław Szydłowski).

37 Biblioteka Naukowa PAU i PAN, Zbiory Specjalne, sygn. 1996, Korespondencja S. Tomkowicza, k. 198-198vº - List od S. Turczyńskiego, 26 V 1923. P. Biliński, Sprawa..., s. 129 podaje, że rozmowy z Ministerstwem toczyły się już w r. 1919.

${ }^{38}$ Biblioteka Naukowa PAU i PAN, Zbiory Specjalne, sygn. 1996, Korespondencja S. Tomkowicza, k. 19-20 - List od A. S. Sapiehy, 12 IV 1927.

${ }^{39}$ S. Tomkowicz, Zbiór dawnych sztychów po śp. Jerzym Moszyńskim, „Czas”, 1929, nr 176 (4 VIII), s. 2-3 - artykuł zacytowany pod innym tytułem w: K. Krużel, op. cit., s. 203, przyp. 10. 
Jarosławiecka z polecenia Komisji Historii Sztuki PAU, której przewodniczącym był wówczas Tomkowicz. Działo się to w czerwcu r. $1926^{40}$, a więc jeszcze przed odnalezieniem większości kolekcji graficznej przechowywanej w Paryżu, w tzw. Izbie Schultza. Jej odkrycie we wrześniu r. 1926 zmusiło PAU do podjęcia działań nie przewidzianych w pierwotnych planach restrukturyzacji Biblioteki. W obliczu konieczności szybkiego i kompetentnego skatalogowania odnalezionego zbioru, Franciszek Pułaski właśnie z Tomkowiczem konsultował zakres i sposób inwentaryzacji. Ten ostatni wyraził również zgodę na dalszą pracę Jarosławieckiej w Paryżu ${ }^{41}$. Wreszcie to on przemówił na wspomnianym powyżej otwarciu wystawy w Pałacu Sztuki w r. 1931, ale - w przeciwieństwie do Tadeusza Szydłowskiego - nie wspomniał o planach związanych z przyszłością kolekcji. Tomkowicz wygłosił opinię, którą można uznać za wyraz jego osobistej wrażliwości na sztukę graficzną:

[...] wystawy sztychów nie bywają zdarzeniem zbyt częstem i częstemi być nie mogą. Nie widzimy na nich obrazów o barwach jaskrawych, przyciągających oczy nawet mało ze sztuką oswojone, wołających z daleka nawet na dziecko małe: patrz na mnie. Dają one jakby idealny ekstrakt malarstwa, wyciąg tego, co w dziełach sztuki jest pierwiastkiem najsubtelniejszym, stroną najbardziej oderwaną i duchową: pomysły obrazów, oddane jak najmniej materialnie, najmniej krzykliwie. Stąd zbiór sztychów nie jest przynętą dla szerokiego ogółu, szukającego wrażeń grubych i pospolitych, ale jest on rozkoszą dla natur delikatniejszych, ucztą dla ludzi wykwintnych, jest też szkołą dobrego smaku $^{42}$.

Rozważając kwestię ewentualnych orędowników powstania Gabinetu, warto byłoby bliżej przyjrzeć się działaniom Leonarda Lepszego, Tadeusza Szydłowskiego oraz Leona Pinińskiego. Dwaj pierwsi, jak już wspomniano, pracowali w komisji opiniującej wartość zbioru Fryderyka Moszyńskiego, ponadto Lepszy w latach 1927-1933 jeden z wiceprezesów Towarzystwo Przyjaciół Sztuk Pięknych w Krakowie - mógł zachęcać władze Towarzystwa do współorganizacji wystawy w r. 1931.Wreszcie Lepszy przekazał dla Gabinetu Rycin swój egzemplarz słownika Thiemego i Beckera ${ }^{43}$. Leon Piniński został zaś pierwszym przewodniczącym Komitetu Gabinetu Rycin powołanego w r. 1934 i otwierał uroczystą inaugurację Gabinetu w r. 1935. Korespondencja z sekretarzem generalnym PAU dowodzi jego słabej znajomości historii zbioru paryskiego, ale równocześnie dobrej orientacji w kwestiach natury organizacyjnej. Potwierdzeniem zaangażowania Pinińskiego

${ }^{40}$ AN PAN i PAU Kr, PAU, sygn. I-126 (Stacja Naukowa w Paryżu), Sprawozdanie z oględzin Biblioteki Polskiej złożone przez F. Pułaskiego dla PAU 8 X 1926. W załączonym Protokole lustracji Biblioteki Polskiej w Paryżu w dniach od 20 do 26 września 1926 r., punkt IV: Inwentarze i katalogi zbiorów (k. 19) - katalogowanie rycin rozpoczęte z polecenia „komisja do badania hist. szt. w Polsce P.A.U. w czerwcu 1926".

${ }^{41}$ Biblioteka Naukowa PAU i PAN, Zbiory Specjalne, sygn. 1991, Korespondencja S. Tomkowicza, k. 114-115 - list Pułaskiego, 12 IV 1927.

${ }^{42}$ An., Otwarcie wystawy starych sztychów, „Czas”, 1931, nr 277 (1 XII), s. [3]. Opinia Tomkowicza potwierdzona, w: Wystawa sztychów w Krakowie, „Czas” 1931, nr 273 (26 XI), s. [3].

43 „Rocznik PAU. Rok 1937/1938”, Kraków 1939, s. 21. 
w powstanie Gabinetu Rycin PAU jest wzmianka w jego nekrologu ${ }^{44}$ : publikacja $\mathrm{z}$ pozoru mało istotna, ale uwzględniająca $\mathrm{w}$ nekrologu fakt nie wymieniany przez innych członków wspomnianego Komitetu ${ }^{45}$.

Do zwolenników powstania Gabinetu Rycin zapewne należał także Julian Pagaczewski (1874-1940) ${ }^{46}$, od r. 1933 przewodniczący Komisji Historii Sztuki PAU. Wypromował on swych bliskich współpracowników - Bochnaka i Estreichera - na kustosza i pomocnika kustosza (adiunkta). Adam Bochnak sprawował też funkcję sekretarza Komitetu, a na przełomie 1938 i 1939 ofiarował do zbiorów dwie akwarele Krzysztofa Lubienieckiego ${ }^{47}$. Jego ówczesne zaangażowanie w organizację zbiorów graficznych nie znajduje jednak znaczącej kontynuacji w bardzo różnorodnej działalności naukowej Bochnaka ${ }^{48}$. W swych pracach naukowych, zwłaszcza dotyczących problemów tak związanych ze sztuką graficzną jak fundacje króla Zygmunta Starego, twórczość Wita Stwosza czy srebrne puszki w kolegiacie w Łowiczu jedynie ogólnie wzmiankował nawiązania do rycin ${ }^{49}$, ale np. nie poświęcił uwagi Gabinetowi Rycin w omówieniach dziejów historii sztuki ${ }^{50}$. Odpowiedź na pytanie, dlaczego tak się stało, pozostaje otwarta. Warto jednak podjąć próbę pogłębienia analizowanych tu kwestii, aby nie poprzestać na informacjach zawartych w narcystycznych i podkolorowanych, a w szczegółach mało wiarygodnych wspomnieniach Karola Estreichera. Badacz ten w marcu r. 1935 został adiunktem w Gabinecie Rycin, dwa miesiące później nadzorował przeniesienie kolekcji Moszyńskiego z Biblioteki Jagiellońskiej ${ }^{51}$, w tym samym roku opublikował notatkę w „Biuletynie Historii Sztuki i Kultury" ${ }^{52}$ oraz oprowadzał gości po wystawie rycin angielskich. Niemniej

${ }^{44}$ T. Mańkowski, Leon Piniński (1857-1938), „Prace Komisji Historii Sztuki”, 7, 1937, s. 265 267; idem, Wspomnienie pośmiertne: Leon Piniński (1857-1938), „Rocznik Towarzystwa Naukowego Warszawskiego", 31-38, 1938-1945, s. 234-235.

${ }^{45}$ Włącznie z nekrologiem pierwszego Dyrektora zbiorów - Pagaczewskiego (A. Bochnak, Julian Pagaczewski (14 I 1874-13 XI 1940), „Prace Komisji Historii Sztuki”, 8, 1946, z. 1, s. 225-237).

${ }^{46}$ Por. A. Małkiewicz, Julian Pagaczewski (1874-1940), „Rocznik Historii Sztuki”, 36, 2011, s. $21-28$.

47 „Rocznik Polskiej Akademii Umiejętności. Rok 1938/1939”, 1945, s. 20. Rysunki pochodziły ze spuścizny po J. Mycielskim (A. Treiderowa, Kolekcja..., s. 69-70).

${ }^{48}$ Por. A. Małkiewicz, Adam Bochnak [w:] Stulecie Katedry..., s. 97-108.

${ }^{49}$ A. Bochnak, Dwie puszki srebrne z herbami Wazów w kolegiacie łowickiej (komunikat), „Prace Komisji Historii Sztuki”, 6, 1934, s. 46*-49*, zwłaszcza s. 47; idem, Wit Stwosz w Polsce, Warszawa 1950 (nie uwzględnił żadnej niemiecko-języcznej literatury na ten temat); idem, Mecenat Zygmunta Starego w zakresie rzemiosła artystycznego, „Studia do dziejów Wawelu”, 2, 1960, s. 131-301 (wzmiankuje pierwowzory Albrechta Dürera, ale nie wspomina o wzorach ornamentalnych, a te miały zasadnicze znaczenia dla zdobnictwa omawianych fundacji królewskich).

${ }^{50}$ A. Bochnak, Historia sztuki [w:] Polska Akademia Umiejętności 1872-1952. Nauki humanistyczne i spoleczne. Materiały sesji jubileuszowej, Kraków, 3-4 V 1973, red. Jan Hulewicz i in., Wrocław 1974, s. 235-248.

${ }^{51}$ P. Biliński, Sprawa..., s. 141.

${ }^{52}$ K. Estreicher, Kronika z Krakowa. Gabinet grafiki P.A.U., „Biuletyn Historii Sztuki i Kultury”, 3, 1935, nr 3, s. 272. 
jednak, w swym Dzienniku wypadków, mieni się jednym z dwóch (obok Bochnaka) prowadzących Gabinet Rycin, podstępnie pozbawionym stanowiska po II wojnie światowej przez Tadeusza Mańkowskiego $(1878-1956)^{53}$. Estreicher pozostaje też autorem trudno dostępnej pracy o Falcku i Chodowieckim ${ }^{54}$, uznanej przez Eugeniusza Iwanoykę „za mało wnoszącą" ${ }^{55}$.

Dopiero na posiedzeniu publicznym Akademii w dniu 16 czerwcu 1934 sekretarz generalny Stanisław Kutrzeba po raz pierwszy ogłosił plany otwarcia nowej instytucji. Na pomieszczenie zbiorów przeniesionych z Biblioteki Polskiej i zakupionych po Jerzym Moszyńskim, w sumie szacowanych na ok. 40 tysięcy rycin, przeznaczono pierwsze piętro kamienicy Hussarzewskich. Po podjętym już remoncie, w sześciu (potem czterech) pokojach „urządzoną będzie stała wystawa rycin”, obok miały się mieścić: sala zebrań Komisji historii sztuki PAU oraz pracownie Gabinetu pozostającego pod opieką osobnego Komitetu. Pozostałe „ubikcje” przeznaczono na miejsce pracy innych Komitetów. Uroczyste otwarcie planowano na jesieni r. $1934^{56}$. Wówczas znany musiał być też skład Komitetu Gabinetu Rycin, sprawującego nadzór nad nową jednostką. Weszli do niego: Leon Piniński - przewodniczący, Julian Pagaczewski - zastępca, Adam Bochnak - sekretarz oraz członkowie: Stefan Komornicki (1887-1942), Feliks Kopera (1871-1952), Tadeusz Szydłowski i Władysław Tatarkiewicz (1886-1980). Dyrektorem Zbiorów, który zgodnie z regulaminem piastował jednocześnie funkcję przewodniczącego KHS, był Julian Pagaczewski, a kustoszem - Adam Bochnak ${ }^{57}$. Koszt prac remontowych i organizacyjnych w Domu im. Hussarzewskich wyniósł w r. 1934 ponad trzydzieści sześć tysięcy złotych, w tym ponad pięć tysięcy przeznaczono na urządzenie Gabinetu Rycin ${ }^{58}$. Prace musiały jednak zostać przedłużone, gdyż nominację na Dyrektora zbiorów Pagaczewski otrzymał dopiero w marcu r. 1935, przed pierwszym planowanym uroczystym otwarciem. Przyjmując dyrekturę domagał się zmiany określenia funkcji swych współpracowników - dwóch ,urzędników muzealnych” jak ich zwał z „kustosza” na „konserwatora” i z ,pomocnika kustosza” na ,adiunkta”. Propozy-

${ }^{53}$ K. Estreicher, Dziennik Wypadków. T. II: 1946-1960, Kraków 2002, s. 49. Jego enuncjacje weszły już niestety do naukowego obiegu na prawach wiarygodnego źródła - P. Hübner, Zwierciadło nauki. Mała encyklopedia polskiej nauki akademickiej, Kraków 2013, s. 593.

${ }^{54}$ K. Estreicher, Falck Polonus i Chodowiecki Polak [w:] Studia z dziejów kultury polskiej, red. H. Barycz, J. Hulewicz, Warszawa 1949.

55 E. Iw anoyk o, Jeremiasz Falck Polonus. Ze studiów nad grafika Polska XVII w., Poznań 1952, s. 3, przyp. 4. Estreicher poczuł się tak głęboko urażony ta opinią, że posunął się do publicznego oskarżenia Iwanoyki o plagiat - K. Estreicher, Dziennik..., s. 366-367 (tu podaje, że praca ukazała się nie w r. 1949, lecz w 1939 w gdańskich „Wiadomościach Literackich”).

${ }^{56}$ S. Kutrzeba, Sprawozdanie Sekretarza Generalnego Polskiej Akademii Umiejętności za czas od czerwca 1933 do czerwca 1934 r., „Rocznik Polskiej Akademii Umiejętności. Rok 1933/1934”, 1935, s. 111-112.

57 „Rocznik Polskiej Akademii Umiejętności. Rok 1933/1934”, 1935, s. LXIII-LXIV; K. Krużel, op. cit., s. 207-208.

58 AN PAN i PAU Kr, PAU KSG, sygn. 377/1935 - Druk szczegółowego zestawienia wydatków PAU za rok 1934, z datą 25 III 1935. 
cje zostały przyjęte ${ }^{59}$. Nasuwa się konstatacja, że pomiędzy marcem a czerwcem r. 1935, kiedy nastąpiło oficjalne otwarcie Gabinetu Rycin, we władzach PAU zaszła znacząca zmiana w podejściu do nowej placówki. Świadczy o tym porównanie drukowanych informacji o Walnym Zgromadzeniu PAU z obu tych miesięcy. W druku anonsującym marcowe zebranie figuruje jedynie lakoniczna wzmianka, iż: „odbędzie się otwarcie Domu im. Hussarzewskich" ${ }^{60}$. W kolejnym, czerwcowym informatorze, otwarcie wystawy Gabinetu Rycin awansowało na numer jeden programu (fot. 1). Podwyższenie rangi tego wydarzenia potwierdzają zaproszenia wystosowane przez sekretarza generalnego do pierwszych osób w państwie, czego nie praktykowano przy zwyczajowych Walnych Zgromadzeniach. Najpewniej owa jakościowa zmiana z położeniem nacisku na ekspozycję rycin dokonała się pod wpływem Juliana Pagaczewskiego, Dyrektora Gabinetu.

Nie znamy zasad, na których wyłoniono członków Komitetu i władz Gabinetu. Warto jednak zauważyć, że żadna z osób opracowujących uprzednio zbiory graficzne PAU nie została powołana do Komitetu, choć każda była członkiem Komisji Historii Sztuki i legitymowała się rozlicznymi publikacjami, których tematyka pozostawała bliska problemom grafiki. Dziwnym trafem członkami tego wykluczonego grona były wyłącznie kobiety. Wspomniano już o krytycznym stosunku Stanisławy Sawickiej do zarządzania przez Akademię zbiorem graficznym o charakterze muzealnym. Niewiele wiadomo o zapatrywaniach Marii Jarosławieckiej (od r. 1931 Jarosławieckiej-Gąsiorowskiej) oraz Zofii Ameisenowej. Ta ostatnia związana była z obiema kolekcjami, z których utworzono Gabinet Rycin. Już w lutym r. 1927 uczestniczyła w przyjęciu w Bibliotece Jagiellońskiej w charakterze depozytu kolekcji rycin Fryderyka Moszyńskiego. Wówczas istniała jeszcze pewna nadzieja na zakup tego zbioru przez Bibliotekę ${ }^{61}$. Co ważniejsze, Ameisenowa sporządziła też katalog wystawy w Pałacu Sztuki, z kompetentnymi, choć skrótowymi opisami oraz historią zbioru Moszyńskich we wstępie ${ }^{62}$. Z jej tekstu jednoznacznie wynika, że najważniejszym kryterium wyboru eksponatów były względy natury artystycznej ${ }^{63}$. Niewykluczone, że w czasie pracy nad kolekcją Moszyńskich miała nadzieję na przekazanie rycin do Biblioteki Jagiellońskiej, tak przynajmniej wynika z pośmiertnego wspomnienia, w którym stwierdzono, że sprawa stała się dla niej dramatycz-

${ }^{59}$ AN PAN i PAU Kr, PAU, KSG, sygn. 388/1935 - Nominacja dla Pagaczewskiego, 13 III; jego zgoda $z$ datą 29 III i uwagami co do nazewnictwa, tak aby zgodziły się z terminami używanymi we Francji, Niemczech i Muzeum Czartoryskich. W tym samym dniu nominacje otrzymali Bochnak i Estreicher (KSG 389/1935 i KSG 390/1935). Zmienione określenia funkcji uwzględnia spis w: „Rocznik Polskiej Akademii Umiejętności. Rok 1934/1935”, 1936, s. LXVII-LXVIII.

${ }^{60}$ AN PAN i PAU Kr, PAU KSG, sygn. 377/1935 - Drukowane zawiadomienie o Walnym Zgromadzeniu PAU w dniu 26 III 1935.

${ }^{61}$ P. Biliński, Sprawa..., s. 139.

${ }^{62}$ [Z. Ameisenowa], op. cit., s. 5 - ustaliła, że twórcą kolekcji był Fryderyk Józef, a nie jego brat, August, jak błędnie uważał Tomkowicz i wielu późniejszych badaczy.

${ }^{63}$ [Z. Ameisenowa], op. cit., s. 9. Postawę wrażliwości na wartości estetyczne badaczka prezentowała na każdym polu swych zainteresowań - A. Olszewska, Zofia Ameisenowa (1897-1967), „Rocznik Historii Sztuki”, 36, 2011, s. 94. 
nym przeżyciem ${ }^{64}$. Bliższe informacje może zawierać korespondencja Ameisenowej zastrzeżona testamentalnie do r. $2017^{65}$.

Pominięcie wspomnianych badaczek okazało się brzemienne w skutkach. Nowo powstały Gabinet Rycin, jedyna tego typu placówka w Polsce zorganizowana od podstaw, bez oparcia o instytucję typu muzealnego czy bibliotecznego, został pozbawiony opieki fachowców, którzy zainicjowaliby kierunek jego rozwoju, w tym naukowe opracowanie kolekcji. Co więcej, większość naukowców z Komitetu Gabinetu Rycin nie poświęciła sztuce graficznej - wtedy bądź później - osobnego studium badawczego. Poza wymienioną wyżej pracą Estreichera, jedynie studium o ikonografii Stefana Batorego pióra Stefana Komornickiego uwzględnia wizerunki graficzne króla w oparciu zarówno o polskie, jak i zagraniczne kolekcje $^{66}$.

Wydawałoby się, że zasób Gabinetu stosunkowo łatwo nadawał się do usystematyzowania. Od samego początku dysponowano profesjonalnym katalogiem kolekcji paryskiej sporządzonym zaledwie cztery lata wcześniej przez Sawicką. Jego układ z powodzeniem można było zastosować do pozostałej części zbioru. Tymczasem - jak się zdaje - wysiłek podjętej w Paryżu inwentaryzacji właściwie poszedł na marne, bo wszystkie siły trzech pracowników ${ }^{67}$ zostały skierowane na organizację kolejnych wystaw. I znów warto zadać pytanie, czy ten bieg rzeczy był zgodny z planami założycieli?

Poznanie kulisów powstania Gabinetu Rycin jest istotne dla odpowiedzi na pytanie o celowość tej decyzji oraz jej naturę. Czy była przemyślaną i świadomą próbą ochrony polskiej spuścizny kulturalnej i upowszechnienia wiedzy o sztuce graficznej? Z rozpoznanych źródeł zdaje się wynikać, że mogła zostać podjęta z partykularnych pobudek, choćby takich, jak stworzenie łatwego dostępu do źródeł ikonograficznych czy pochwalenie się dyrekturą samodzielnego zbioru. Utworzenie przy Komisji Historii Sztuki PAU jednostki stricte muzealnej stało w sprzeczności z zadaniami naukowymi i wydawniczymi, które sama Komisja sobie wytyczyła i konsekwentnie realizowała ${ }^{68}$. Budzą się więc obawy, czy racja nie leżała po stronie Sawickiej, obawiającej się zmarnowania potencjału kryjącego się w dobrze zarządzanym zbiorze rycin, a znającej „od podszewki” sposób podejmowania decyzji w łonie PAU, w zamkniętym kręgu towarzysko-naukowym, obejmującym mistrza i jego ulubionych (czasem najzdolniejszych) uczniów. Osobną kwestią pozostaje

${ }^{64}$ Z. Ciechanowska, S. Korajska, Zofia Ameisenowa (1897-1967), „Biuletyn BJ”, XIX, 1969, s. 143.

${ }^{65}$ A. Olszewska, op. cit., s. 92.

${ }^{66}$ E. S. Komornicki, Essai d'une iconographie du Roi Etienne Batory, Cracovie 1935 - praca wydana pod patronatem PAU i Węgierskiej Akademii Nauk.

${ }^{67}$ K. Kruże1, op. cit., s. 209.

${ }^{68}$ L. Kalinowski, Dzieje i dorobek naukowy Komisji Historii Sztuki Akademii Umiejętności i Polskiej Akademii Umiejętności 1873-1952 oraz powstanie Katedry Historii Sztuki Uniwersytetu Jagiellońskiego 1882 [w:] Dzieje historii sztuki w Polsce. Ksztattowanie się instytucji naukowych w XIX i XX wieku, red. A. S. Labuda, Poznań 1996, s. 31. 
szczegółowe wyliczenie ogromnych nakładów finansowych związanych z katalogowanie rycin w Bibliotece Polskiej (częściowo sfinansowanych przez Ministerstwo) i powołaniem Gabinetu, które poprzedziło m.in. zakup zbioru Moszyńskiego i remont kamienicy Hussarzewskich; do tego należy doliczyć wyposażenie Gabinetu, m.in. w sprzęt ekspozycyjny oraz płace pracowników.

Gabinet Rycin wciąż nie został uwzględniony w kontekście aktywności ówczesnego krakowskiego środowiska naukowego oraz zainteresowań jego przedstawicieli sztukami graficznymi. Czas tu na postawienie ostatniego pytania o powody tak niewielkiego zainteresowania dziejami naszej instytucji. Niewątpliwie wpływ na ten stan rzeczy miał krótki okres działalności Gabinetu (1935-1939, 1945-1953). Można tu postawić tezę o innej przyczynie tego stanu rzeczy: braku publikacji na temat zbiorów, w pierwszym rzędzie katalogów prezentowanych wystaw. Spektakularnym przykładem znaczenia tego rodzaju publikacji są np. katalogi wystaw we wnętrzach pałacu Pusłowskich w Krakowie czy prezentacja portretów za zbiorów graficznych Dominika Witke-Jeżewskiego (1862-1944) w Warszawie ${ }^{69}$. Na ich tle nadzwyczaj skromnie prezentują się enuncjacje prasowe dotyczące Gabinetu Rycin ${ }^{70}$, a jedynie nimi oraz archiwaliami dysponujemy - jako że archiwalne spisy pozostają niedostępne szerokim kręgom badaczy - chcąc zaznajomić się z ówczesnym zasobem. Trudno więc dziwić się znikomej naukowej recepcji zbiorów graficznych PAU. Analogicznie, zgromadzone u zarania istnienia Akademii Umiejętności dzieła sztuki, w tym rysunki i ryciny, które na przełomie w. XIX i XX zdecydowano się zdeponować (w praktyce: przekazać) w Muzeum Narodowym w Krakowie w świadomości niemal wszystkich zajmujących się dziś nimi badaczy nie mają ważnej metryki historycznej. W ogromnym zasobie Muzeum Narodowego zatraciła się ta ważna część ich losu, jaką było wieloletnie przechowywanie przy ul. Sławkowskiej 17. Krakowska historia sztuki nie wykazała dostatecznego zainteresowania należnego temu, w większości zachowanemu, historycznemu zasobowi. Spektakularnym tego przykładem pozostaje sposób potraktowania zasobów PAU w Katalogu Zabytków Sztuki w Polsce ${ }^{71}$.

W dobie zainteresowania dziejami historii sztuki można mieć nadzieję, że poruszone tu wątki staną się inspirujące dla innych badaczy, przede wszystkim historyków obeznanych ze specyfiką dwudziestowiecznych źródeł, tylko pozornie łatwych do interpretacji. Wciąż bowiem odczuwamy brak monograficznych opracowań

${ }^{69}$ Portret królewski w grafice. Katalog wystawy Tow. Opieki nad Zabytkami Przeszłości urządzonej ze zbiorów Dominika Witke-Jeżewskiego, Warszawa 1925; Wystawa starych zegarów na tle wnętrz pałacu hr. Pusłowskich, Kraków 1938; K. Buczkowski, Z. Przeorska-Exnerowa, Wystawa miniatur na tle wnętrz pałacu hr. Pustowskich, Kraków 1939.

70 Polska Bibliografia Sztuki 1801-1944, t. II, Rysunek, grafika, sztuka ksiązki i druku, oprac. J. Wiercińska, M. Liczbińska, s. 9, nr 94-95a (wystawy mylnie wpisane i zindeksowane pod hasłem: Kraków - Biblioteka PAU).

${ }^{71}$ Katalog Zabytków Sztuki w Polsce, t. IV: Miasto Kraków, cz. XI: Sródmieście. Ulica Stawkowska, oprac. P. Dettloff, Warszawa 2012, s. 49-53. 
opartych o rzetelną faktografię ${ }^{72}$; dotyczy to na dobrą sprawę niemal wszystkich krakowskich kolekcji muzealnych. Dalsze poszukiwania winny przede wszystkim skoncentrować się na wyświetleniu motywacji założycieli Gabinetu Rycin i najwcześniejszych losów tej pięknej idei.

\section{MAGDALENA ADAMSKA}

THE PRINT ROOM OF THE POLISH ACADEMY OF ARTS AND SCIENCES AN EPISODE FROM THE HISTORY OF THE POLISH HISTORY OF ART

\section{Summary}

The year 2015 marks the 80th anniversary of the opening of the Print Room, a new branch of the Polish Academy of Arts and Sciences housing prints, the forerunner of the present Print Room of the Scientific Library. It functioned independently only for a relatively short time (1935-1939 and 19451953, the gap due to the Second World War). Despite this fact, the Print Room and its's collection (over 40 thousands prints) is worth our attention. As an exception in the history of the Polish print collections, it was established at a great cost by a scientific institution with no practical support from a museum group or librarians.

The authors discussing the history of the Print Room (e.g.K. Krużel, The Print Collection of the Polish Academy of Sciences, „Print Quarterly”, XI, 1994, 2, s. 158-166; see note 1) seem to determine the establishment with two facts: the recovery of the print collection in the Polish Library in Paris being restored those days (1926) and the purchase of the Moszyński print collection (1929). However, there is still no answer to the questions concerning the time the decision was made, the people engaged in the establishment and also the Prints Room's objectives. Since the beginning of the 30ties there were two main concepts regarding the future of the newly acquired prints. First, the proposition was made to incorporate them into one of the existing collections. On the other hand, the idea of creating a new institution was put forward. According to this last opinion, the institution should have spread the knowledge about the graphic art and the history of the printmaking through subsequent presentation. The Print Room created in 1934, and ceremonially opened to the public in 1935, realized boththe expositional and educational programs. The opening was celebrated with an exhibition of English prints, still preserved in the Print Room of the Scientific Library (Figs. 3-8).

The article is an attempt to draw the attention to the problems mentioned above. Their solution requires detailed analysis the archival material concerning Academy itself as well as the legacies its individual members.

${ }^{72}$ W rodzaju wyczerpującego studium: P. Biliński, Sprawa... 